ASTHMA

\title{
Raised cord serum immunoglobulin $E$ increases the risk of allergic sensitisation at ages 4 and 10 and asthma at age 10
}

\author{
A Sadeghnejad, W Karmaus, S Davis, R J Kurukulaaratchy, S Matthews, S H Arshad
}

Thorax 2004;59:936-942. doi: 10.1136/thx.2004.024224

See end of article for authors' affiliations

.....................

Correspondence to: Dr W Karmaus, Department of Epidemiology, Michigan State University, East Lansing, Michigan, USA; karmaus@msu.edu

Received 4 March 2004 Accepted 28 August 2004
Background: Evidence suggests that a raised level of cord serum lgE (CS-lgE) is a risk factor for allergic sensitisation. However, whether CS-lgE is a risk for asthma is controversial. A study was undertaken to investigate the association between CS-lgE levels and allergic sensitisation at 4 and 10 years of age and asthma at ages $1-2,4$ and 10 .

Methods: CS-lgE was available for 1358 of 1456 children born between 1989 and 1990. The cohort was evaluated for allergic diseases at ages 1, 2, 4 and 10 years. Skin prick tests for six allergens were performed on 981 children at age 4 and 1036 at age 10. Asthma was defined based on a physician's diagnosis. Using logistic regression analysis, the risk of asthma and allergic sensitisation for raised levels of $\mathrm{CS}-\lg E(\geqslant 0.5 \mathrm{kU} / \mathrm{l})$ was estimated.

Results: At ages 4 and 10 years $20.2 \%$ and $27.0 \%$ of children, respectively, had allergic sensitisation. The risk of allergic sensitisation was significantly associated with raised CS-lgE levels at ages 4 (OR 2.29) and 10 years (OR 1.73). The prevalence of asthma was $10.3 \%$ at age $1-2,15.2 \%$ at age 4 , and $12.8 \%$ at age 10. CS-lgE was not associated with asthma at age $1-2$ and 4 but showed an increased relative risk at age 10 (OR $1.66,95 \% \mathrm{Cl} 1.05$ to 2.62). The association was stronger in children who did not develop allergic sensitisation at age 4 or 10 (OR $3.35,95 \% \mathrm{Cl} 1.41$ to 7.93 ).

Conclusions: Raised cord serum lgE is a risk factor for allergic sensitisation at ages 4 and 10 years. This is the second study suggesting that CS-IgE is also a risk factor for asthma at age 10, probably related to the late onset of asthma. This association is not necessarily mediated by allergic sensitisation.
$\mathrm{T}$ here is evidence that factors early in life have major effects on the later development of allergy (atopy). ${ }^{1-8} \mathrm{~A}$ correlation between serum IgE levels during the first year of life and atopic diseases in the first 2 years of life was first reported in 1975 by Orgel et al, who proposed that serum IgE might be used as a predictor for allergic diseases. ${ }^{7}$ Subsequent studies examined the use of cord serum $\operatorname{IgE}$ (CS-IgE) as a biomarker for atopic diseases but the results were conflicting. ${ }^{18-14}$ One limitation of these studies is that only early childhood manifestations (up to 5 years) were investigated, ${ }^{6} 7^{1015}$ with the exception of a Swedish study that followed newborns to the age of $11 .{ }^{8}$ In addition, almost all of the previous studies used total CS-IgE (Nambu et al investigated CS-IgE specific to a particular allergen). Comparisons of studies are further complicated by their use of different allergic outcomes.

The Isle of Wight cohort was established in 1989 to study the risk factors for atopy and its development during childhood. The first examination of CS-IgE in this cohort found it to be an insensitive predictor of asthma, eczema, and hay fever in the first year of life. ${ }^{16}$ A subsequent study of 4 year old children by Tariq et a ${ }^{17}$ showed that raised CS-IgE levels increased the risk of aeroallergen sensitisation without increasing respiratory allergic symptoms. The purpose of the current study is to investigate the association between CS-IgE levels and both allergic sensitisation and asthma in the Isle of Wight cohort up to the age of 10 years.

\section{METHODS}

\section{Study population}

After approval by the local research ethics committee, 1456 children born between January 1989 and February 1990 on the Isle of Wight, UK were recruited. Informed written parental consent was obtained for all participants. To measure cord serum IgE, samples were obtained from 1358 newborn infants.

\section{Questionnaire and examination}

In the first survey at the time of the child's birth, parents were asked about their age, maternal smoking during pregnancy, and history of asthma, hay fever, and atopic eczema. At 1 and 2 years of age a questionnaire was administered seeking information on symptoms suggestive of allergic disease in children.

At 4 years of age all children and their parents were invited to attend the allergy clinic; ${ }^{18} 981$ (67\% of the original cohort) attended and a questionnaire was completed and a physical examination conducted. A follow up questionnaire (postal or telephone) was used to gather information from an additional 237 children who had not attended the clinic, giving a total of 1218 children (84\% of the original cohort). Some families did not participate in the study because they moved from the Isle of Wight, while others declined to have their child skin prick tested. Questionnaire information was collected on the presence of allergic diseases. Birth order data and details of environmental factors such as parental smoking, exposure to pets, and housing conditions were also recorded.

At 10 years of age the information was updated and a physical examination was conducted during a visit to the research centre $(n=1043)$. Detailed interviewer administered questionnaires regarding asthma and allergy development were completed with a parent of each child. ISAAC

Abbreviations: CS-lgE, cord serum immunoglobulin E; SPT, skin prick test 


\begin{tabular}{|c|c|c|c|c|}
\hline \multirow[b]{2}{*}{ Variable } & \multirow[b]{2}{*}{ No at birth (\%) } & \multicolumn{2}{|c|}{ Percentage by levels of CS-IgE } & \multirow{2}{*}{$\begin{array}{l}p \text { value } \\
\left(\chi^{2} \text { test }\right)\end{array}$} \\
\hline & & $<0.5$ & $\geqslant 0.5$ & \\
\hline Total & 1358 & 87.2 & 12.8 & \\
\hline \multicolumn{5}{|l|}{ Sex } \\
\hline Male & $696(48.7)$ & 86.6 & 13.4 & \multirow{3}{*}{0.54} \\
\hline Female & $661(51.2)$ & 87.8 & 12.2 & \\
\hline Missing & $1(0.1)$ & 100 & 0.0 & \\
\hline \multicolumn{5}{|l|}{ Birth weight (g) } \\
\hline$<1500$ & $27(2.0)$ & 88.9 & 11.1 & \multirow[t]{4}{*}{0.76} \\
\hline $1500-2500$ & 44 (3.3) & 87.2 & 12.8 & \\
\hline $2500-4000$ & $1124(82.8)$ & 90.9 & 9.1 & \\
\hline$>4000$ & $163(12.0)$ & 85.3 & 14.7 & \\
\hline \multicolumn{5}{|c|}{ Neonatal complications } \\
\hline Yes & $188(13.8)$ & 85.6 & 14.4 & \multirow[t]{2}{*}{0.76} \\
\hline No & 1170 (86.2) & 87.4 & 12.6 & \\
\hline \multicolumn{5}{|c|}{ Having a pet at recruitment } \\
\hline Yes & $779(56.6)$ & 87.0 & 13.0 & \multirow[t]{2}{*}{0.81} \\
\hline No & $589(43.4)$ & 87.4 & 12.6 & \\
\hline \multicolumn{5}{|l|}{ Season of birth } \\
\hline Spring & $315(56.3)$ & 87.2 & 12.8 & \multirow[t]{4}{*}{0.13} \\
\hline Summer & $305(56.3)$ & 87.9 & 12.1 & \\
\hline Autumn & $296(56.3)$ & 83.1 & 16.9 & \\
\hline Winter & $442(56.3)$ & 88.5 & 11.5 & \\
\hline \multicolumn{5}{|c|}{ Age of mother at delivery (years) } \\
\hline$\leqslant 23$ & $389(28.6)$ & 86.1 & 13.9 & \multirow[t]{4}{*}{0.54} \\
\hline $24-33$ & $801(59.0)$ & 87.4 & 12.6 & \\
\hline$\geqslant 34$ & $145(10.7)$ & 89.7 & 10.3 & \\
\hline Missing & $23(1.7)$ & 82.6 & 17.4 & \\
\hline \multicolumn{5}{|c|}{ Maternal smoking during pregnancy } \\
\hline Yes & $332(24.6)$ & 87.2 & 12.8 & \multirow[t]{3}{*}{0.99} \\
\hline No & $1012(74.5)$ & 87.1 & 12.9 & \\
\hline Missing & $12(0.9)$ & 91.7 & 8.3 & \\
\hline \multicolumn{5}{|c|}{ Maternal history of atopy } \\
\hline Yes & $438(32.3)$ & 84.0 & 16.0 & \multirow[t]{3}{*}{0.02} \\
\hline No & 905 (66.6) & 88.6 & 11.4 & \\
\hline Missing & $15(1.1)$ & 93.3 & 6.7 & \\
\hline \multicolumn{5}{|c|}{ Paternal history of atopy } \\
\hline Yes & $352(25.9)$ & 85.0 & 15.0 & \multirow[t]{3}{*}{0.11} \\
\hline No & $984(72.4)$ & 88.2 & 11.8 & \\
\hline Missing & $23(1.7)$ & 78.3 & 21.7 & \\
\hline
\end{tabular}

written questionnaires were used to assess respiratory, nasal, and dermatological symptoms. ${ }^{19}$ When a visit was not possible, a telephone questionnaire was completed with a parent or a modified postal questionnaire was sent for the parent to complete and return $(\mathrm{n}=330)$.

\section{Extract of birth records}

Data were obtained from hospital records on gestational age, birth weight, and neonatal complications (preterm delivery, fetal distress, newborn infection, jaundice, low blood sugar, hypothermia, congenital abnormalities, etc).

\section{Cord serum IgE determination}

Duplicate measurements of cord IgE were made on serum from umbilical vein blood samples using the Ultra EIA kit (Pharmacia Diagnostics AB, Uppsala, Sweden) which is designed to measure IgE levels between 0.2 and $50 \mathrm{kU} / \mathrm{l}$ in $0.1 \mathrm{ml}$ serum or plasma. It is a solid phase enzyme immunoassay using monoclonal anti-human IgE, which has a high degree of correlation with the Phadebas IgE Prist method $(r=0.99) .{ }^{16}$ Cord IgA levels were measured in samples in which the level of IgE was higher than $0.3 \mathrm{kU} / \mathrm{l}$. Any samples with IgA levels $>10 \mathrm{mg} / \mathrm{l}$ were considered to be contaminated by maternal blood and were excluded. The method of cord IgE estimation has been described in greater detail elsewhere. ${ }^{16} 20$

\section{Diagnostic criteria for asthma}

The study physicians obtained information regarding the presence of allergic symptoms. For asthma, information included the presence and frequency of cough and wheezing, physician diagnosed asthma, and treatment given. At ages 1,2 and 4 the minimum criteria for the diagnosis of asthma included three or more separate episodes of wheeze in the previous 12 months, each lasting at least 3 days. At age 10, asthma was defined as ever having a diagnosis of asthma, in addition to wheeze in the previous 12 months.

\section{Skin prick tests}

Skin prick tests (SPTs) were carried out on children at the age of 4 years $(\mathrm{n}=981)$ and 10 years $(\mathrm{n}=1036)$ using a standard battery of aeroallergens (house dust mite (Dermatophagoides pteronyssinus), grass pollen mix, cat and dog epithelia, Alternaria alternata, and Cladosporium herbarum). Histamine $(0.1 \%)$ in phosphate buffered saline and physiological saline were used as positive and negative controls, respectively. The extracts were obtained from Biodiagnostics, Hamburg, Germany at age 4 and ALK-Abello, Denmark at age 10. Children were advised not to take antihistamines for 72 hours before the clinic appointment. Commercially available lancets (Medipoint Inc, Mineola, NY, USA) were used to prick the epidermis through the allergen extract drops. The tests were read after 15 minutes and a mean wheal diameter ( sum of longest diameter + diameter diagonal to it divided by 2 ) of at least $3 \mathrm{~mm}$ more than the negative control was considered positive. Surrounding erythema was ignored. A child was regarded as sensitised when the reaction to at least one allergen was positive and non-sensitised when all recorded reactions were negative. 
Table 2 Number of children who had a measurement of cord serum lgE level at birth and at different ages by cord serum lgE levels

\begin{tabular}{|c|c|c|c|c|c|c|}
\hline \multirow[b]{2}{*}{$\begin{array}{l}\text { Level of cord } \\
\text { serum } \lg E\end{array}$} & \multirow[b]{2}{*}{$\begin{array}{l}\text { Birth } \\
(n=1358)\end{array}$} & \multirow{2}{*}{$\begin{array}{l}1-2 \text { years } \\
\text { Asthma } \\
(n=1194)\end{array}$} & \multicolumn{2}{|l|}{4 years } & \multicolumn{2}{|l|}{10 years } \\
\hline & & & $\begin{array}{l}\text { Asthma } \\
(\mathrm{n}=1068)\end{array}$ & $\begin{array}{l}\text { SPT } \\
(n=862)\end{array}$ & $\begin{array}{l}\text { Asthma } \\
(\mathrm{n}=1191)\end{array}$ & $\begin{array}{l}\text { SPT } \\
(n=900)\end{array}$ \\
\hline$<0.5$ & $1184(87.2)$ & $1044(87.4)$ & $928(86.9)$ & $748(86.8)$ & 1040 (87.3) & 789 (87.7) \\
\hline$\geqslant 0.5$ & $174(12.8)$ & $150(12.6)$ & $140(13.1)$ & $114(13.2)$ & 151 (12.7) & 111 (12.3) \\
\hline
\end{tabular}

\section{Statistical analysis}

Likelihood ratios (sensitivity/(1-specificity)) were used to compare cut off points for CS-IgE. CS-IgE levels were then dichotomised into $<0.5 \mathrm{kU} / \mathrm{l}$ and $\geqslant 0.5 \mathrm{kU} / \mathrm{l}$. Asthma at age 1-2 years was regarded as positive when at least one positive record was available at either age 1 or 2 years, and negative when there was at least one negative record and no positive record. SPTs and asthma at different ages were treated as dichotomous outcome variables and separate logistic regression models were run. Potential confounders were season of birth (spring: March-May; summer: June-August; autumn: September-November; winter: December-February); sex; birth weight (categorised as <1500 g, 1500-2500 g, 2500$4000 \mathrm{~g}, \geqslant 4000 \mathrm{~g}$ ); neonatal complications (yes, no); maternal age (categorised as 16-23, 24-33, 34 years and older); history of maternal and paternal atopy (asthma, hay fever, atopic eczema); maternal smoking during pregnancy (yes, no); and having a pet at birth (yes, no).

Logistic regression was used to test the effect of CS-IgE levels on sensitisation and asthma, adjusting for the above mentioned potential confounding factors (logistic procedure). We estimated adjusted odds ratios of CS-IgE for SPT results and asthma at different ages. For asthma we also stratified data by SPT status. Adjusted odds ratios of SPT and asthma at different ages were estimated comparing the two levels of CS-IgE. All statistical analyses were performed using the SAS/Stat program (SAS Institute Inc, Cary, NC, USA).

\section{RESULTS}

CS-IgE was determined for 1358 children $193.3 \%$ of the original cohort). The proportion of newborn infants with increased CS-IgE levels $(\geqslant 0.5 \mathrm{kU} / \mathrm{l})$ for various characteristics is shown in table 1. A maternal history of atopic disorders was a significant risk factor for increased CS-IgE. The number of children who had complete information on CS-IgE, SPTs, and all confounders was 862 at age 4 years and 900 at age $10(63.5 \%$ and $66.3 \%$ of the sample with available CS-IgE; table 2). The number of children with complete information on the development of asthma as well as on CSIgE and confounders was 1194 at age 1-2, 1068 at age 4, and 1191 at age 10 (78.6-87.9\% of the sample of 1358; table 2$)$. The proportion of children with raised CS-IgE levels $(\geqslant 0.5 \mathrm{kU} / \mathrm{l})$ in the samples for different outcomes at different ages did not vary substantially (12.3-13.2\%, table 2 ).
Likelihood ratios for different cut off points of CS-IgE indicated the level of risk for allergic sensitisation and asthma at ages 4 and 10 (table 3). The likelihood ratio (LR) is the likelihood that a specific level of a test result would be expected in a child with a disorder compared with the likelihood that that same result would be expected in a child without the disorder. ${ }^{21} \mathrm{CS}$-IgE levels above the detection limit increased the likelihood of the development of allergic sensitisation $(\mathrm{LR}>\mathrm{l})$ but not of asthma. CS-IgE levels of $\geqslant 0.5 \mathrm{kU} / \mathrm{l}$ showed higher LRs in three of the four outcomes and thus provided more confidence in abnormal test results.

A positive SPT was evident in $20.2 \%$ (174/862) of the children at age 4 and in $27.0 \%$ (243/900) at age 10 (table 4 ). CS-IgE was a risk factor for a positive SPT both at age 4 and 10 , but the association was stronger at 4 years of age (table 4 , fig 1). With regard to specific SPTs, the prevalence increased for most allergens. However, the association (OR) between CS-IgE and allergic sensitisation decreased between 4 and 10 years (table 4 ).

At age 1-2 years physician diagnosed asthma occurred in $10.3 \%$ of the children (123/1194, table 5). The prevalence of asthma at age 4 was $15.2 \%(162 / 1068)$ and at age 10 was $12.8 \%$ (152/1191). Logistic regressions were used to test the associations of CS-IgE with asthma at ages 4 and 10. In addition, to assess whether these relationships were mediated by sensitisation, we stratified asthma at age 4 by SPT positivity at age 4 and asthma at age 10 by SPT positivity at age 4 or 10. Table 5 shows that cord serum IgE levels were not associated with asthma at age 4, irrespective of atopic status. The association of CS-IgE with asthma at age 10 had an OR of 1.66 (95\% CI 1.05 to 2.62) which is statistically significant. When stratifying by SPT results, the association lost its significance in children who had a positive SPT at age 4 or 10 (OR 0.83). However, the majority of children had a negative SPT at both ages. In these children the association between CS-IgE and asthma at age 10 became stronger (OR $3.35,95 \%$ CI 1.41 to 7.93$)$. Figure 1 shows that the relative risk (OR) of CS-IgE for asthma increases with increasing age of diagnosis.

The dynamics of the development of asthma are shown in fig 2 . Of the 138 children who were diagnosed with asthma at age 10, only 44 had asthma at age 1-2. Fifty one children were first observed to have asthma at age 10 (37\% of the children with asthma at age 10). For each subgroup in fig 2, the percentage of children with raised cord serum IgE is

Table 3 Likelihood ratios (LR) of allergic sensitisation (skin prick tests) and asthma for different levels of cord serum lgE

\begin{tabular}{|c|c|c|c|c|c|c|c|c|c|c|c|c|}
\hline \multirow[b]{2}{*}{ Cord lgE (kU/l) } & \multicolumn{3}{|c|}{ SPT at age 4} & \multicolumn{3}{|c|}{ SPT at age 10} & \multicolumn{3}{|c|}{ Asthma at age 4} & \multicolumn{3}{|c|}{ Asthma at age 10} \\
\hline & + & - & LR & + & - & LR & + & - & LR & + & - & LR \\
\hline$>$ detection limit (0.06) & 76 & 297 & 1.27 & 124 & 273 & 1.23 & 69 & 396 & 1.04 & 73 & 447 & 1.12 \\
\hline$\geqslant 0.25$ & 67 & 228 & 1.46 & 102 & 209 & 1.32 & 58 & 308 & 1.05 & 59 & 351 & 1.15 \\
\hline$\geqslant 0.50$ & 31 & 83 & 1.86 & 43 & 68 & 1.71 & 21 & 119 & 0.98 & 28 & 123 & 1.56 \\
\hline Total (n) & 144 & 718 & - & 243 & 657 & - & 162 & 902 & - & 152 & 1039 & - \\
\hline
\end{tabular}

SPT, skin prick test. 
Table 4 Odds ratios (ORs) and confidence intervals (CI) for the risk of sensitisation with raised CS-IgE levels (logistic regression analysis)

\begin{tabular}{|c|c|c|c|c|c|c|}
\hline \multirow[b]{2}{*}{ Age } & \multirow[b]{2}{*}{ Skin prick test } & \multirow[b]{2}{*}{$\begin{array}{l}\text { Total sample } \\
\text { (N) }\end{array}$} & \multicolumn{2}{|c|}{ Cord serum IgE levels } & \multirow[b]{2}{*}{$\begin{array}{l}\text { Unadjusted OR } \\
(95 \% \mathrm{Cl})\end{array}$} & \multirow[b]{2}{*}{$\begin{array}{l}\text { Adjustedt OR } \\
(95 \% \mathrm{Cl})\end{array}$} \\
\hline & & & $\begin{array}{l}<0.5 \mathrm{kU} / \mathrm{l} \\
\%(\mathrm{n} / \mathrm{N})\end{array}$ & $\begin{array}{l}\geqslant 0.5 \mathrm{kU} / \mathrm{I} \\
\%(\mathrm{n} / \mathrm{N})\end{array}$ & & \\
\hline 4 years & $\begin{array}{l}\text { Any } \\
\text { House dust mite } \\
\text { Grass pollen } \\
\text { Cat } \\
\text { Dog } \\
\text { Alternaria } \\
\text { Cladosporium }\end{array}$ & 862 & $\begin{array}{l}18.1 \%(135 / 748) \\
11.8 \%(85 / 748) \\
7.1 \%(53 / 748) \\
4.8 \%(36 / 748) \\
2.1 \%(16 / 748) \\
4.0 \%(30 / 748) \\
2.1 \%(16 / 748)\end{array}$ & $\begin{array}{l}34.2 \%(39 / 114) \\
16.7 \%(19 / 114) \\
14.9 \%(17 / 114) \\
14.0 \%(16 / 114) \\
5.3 \%(6 / 114) \\
12.3 \%(14 / 114) \\
3.5 \%(4 / 114)\end{array}$ & $\begin{array}{l}2.36(1.54 \text { to } 3.63)^{*} \\
1.56(0.91 \text { to } 2.68) \\
2.30(1.28 \text { to } 4.13) \\
3.23(1.73 \text { to } 6.04) \\
2.54(0.97 \text { to } 6.64) \\
3.35(1.72 \text { to } 6.53) \\
1.66(0.55 \text { to } 5.07)\end{array}$ & $\begin{array}{l}2.29(1.47 \text { to } 3.57)^{*} \\
1.47(0.85 \text { to } 2.57) \\
2.29(1.25 \text { to } 4.19) \\
3.19(1.67 \text { to } 6.08) \\
2.34(0.85 \text { to } 6.43) \\
3.18(1.59 \text { to } 6.35) \\
1.79(0.55 \text { to } 5.86)\end{array}$ \\
\hline 10 years & $\begin{array}{l}\text { Any } \\
\text { House dust mite } \\
\text { Grass pollen } \\
\text { Cat } \\
\text { Dog } \\
\text { Alternaria } \\
\text { Cladosporium }\end{array}$ & 900 & $\begin{array}{l}25.3 \%(200 / 789) \\
18.6 \%(147 / 789) \\
11.7 \%(92 / 789) \\
7.7 \%(61 / 789) \\
3.5 \%(28 / 789) \\
1.9 \%(15 / 789) \\
1.3 \%(10 / 789)\end{array}$ & $\begin{array}{l}38.7 \%(43 / 111) \\
26.1 \%(29 / 111) \\
23.4 \%(26 / 111) \\
9.9 \%(11 / 111) \\
8.1 \%(9 / 111) \\
2.7 \%(3 / 111) \\
0.0 \%(0 / 111)\end{array}$ & $\begin{array}{l}1.86(1.23 \text { to } 2.82)^{*} \\
1.55(0.98 \text { to } 2.45) \\
2.77(1.66 \text { to } 4.63) \\
1.31(0.67 \text { to } 2.58) \\
2.40(1.10 \text { to } 5.23) \\
1.43(0.41 \text { to } 5.03) \\
\text { Cannot be calculated }\end{array}$ & $\begin{array}{l}1.73(1.13 \text { to } 2.65)^{*} \\
1.42(0.89 \text { to } 2.28) \\
2.20(1.32 \text { to } 3.67) \\
1.14(0.56 \text { to } 2.32) \\
2.19(0.97 \text { to } 4.95) \\
1.22(0.33 \text { to } 4.51)\end{array}$ \\
\hline
\end{tabular}

${ }^{*} \mathrm{p}<0.05$.

†Controlling for sex, maternal smoking during pregnancy, age of mother at delivery, maternal and paternal atopy, season of birth, birth weight, neonatal complications, and having a pet at recruitment.

shown. In children with late onset asthma (developing after 4 and before 10 years), the proportion is substantially higher $(20 \%)$ than, for instance, the subgroup with early onset asthma at age $1-2$ years ( $11.2 \%$, fig 2 ).

\section{DISCUSSION}

Our results show that raised $\operatorname{CS}$ - $\operatorname{IgE}(\geqslant 0.5 \mathrm{kU} / \mathrm{l})$ is a risk factor for allergic sensitisation at ages 4 and 10 years, and for asthma at age 10 years but not at age $1-2$ or 4 years. To our knowledge, this is the second study to examine the association between CS-IgE and asthma at a later age in childhood.22 Studies over the past three decades conducted on the association between CS-IgE and asthma in childhood are not in agreement. ${ }^{2}{ }^{17}{ }^{22-27}$ Most involved only a small number of children and did not follow them beyond 5 years. ${ }^{23-27}$ In addition, some studies were based only on a clinical assessment of atopy, not on a determination of allergic sensitisation..$^{722}$ Our results corroborate previous studies which found that CS-IgE is a risk factor for allergic sensitisation in early childhood and extend this observation for the first time to the age of 10 years. Our findings also support the report by Croner et $a l^{22}$ that raised CS-IgE increases the incidence of asthma cumulated during childhood up to the age of 11 years (four investigations at 1.5, 3, 7, and 11 years $).{ }^{4822}$

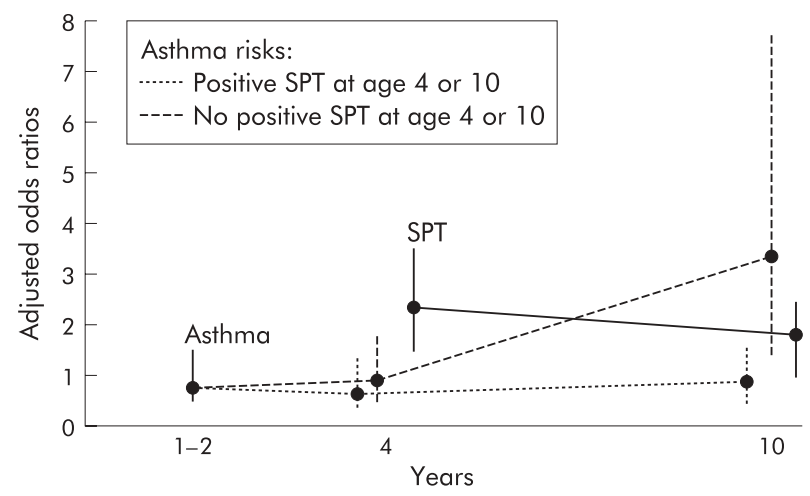

Figure 1 Adjusted odds ratios (OR) of skin prick tests (SPTs) and asthma at different ages for raised levels of cord serum IgE. The dots show the odds ratios and the vertical bars represent $95 \%$ confidence intervals.
The analyses are based on samples of children with complete information on the outcome (sensitisation or asthma), exposure (CS-IgE), and potential confounders. Comparisons of the initial subjects who had CS-IgE measurements $(n=1358)$ with those used in the analyses indicate that selection bias is unlikely (table 2 ).

Contamination of cord blood with maternal blood was assessed using IgA as a biomarker. This led to the exclusion of 86 infants from further analysis. ${ }^{17}{ }^{27}$ Hence, a potential misclassification of cord blood IgE is unlikely. To dichotomise CS-IgE levels, cut off points of $0.5-1.3 \mathrm{kU} / \mathrm{l}$ have been used in previous studies. ${ }^{24822-27}$ We chose to use the cut off point of $0.5 \mathrm{kU} / \mathrm{l} \mathrm{CS}$-IgE for two reasons. Firstly, it has been shown to be the optimal level in previous analyses of this birth cohort ${ }^{17}$ and, secondly, likelihood ratios indicated that the certainty of atopic development is increased for CS-IgE levels of $\geqslant 0.5 \mathrm{kU} /$ l (LR > 1.58 for three of four outcomes). Higher levels of CSIgE were less reliable because of the small number of children (for example, $\geqslant 1.0 \mathrm{kU} / \mathrm{l}$ and asthma at age 10: $\mathrm{n}=9$ ). To assess allergic sensitisation we used skin prick tests which are accepted as an objective marker for evaluating allergic sensitisation. $^{28} 29$ The use of both negative and positive controls reduced the possibility of false results.

IgE production is downstream in a pathway that starts with the presentation of antigens (allergens) to the immune system. This may result in the preferential activation of Th2 cells which are programmed to secrete interleukin (IL)-4 and IL-13 and to induce IgE production. ${ }^{30-32}$ An important question is whether the association of cord IgE levels with asthma is due to its relation with early sensitisation. Our results indicate that the direct effect of CS-IgE disappears in children who developed sensitisation (positive SPT at age 4 or 10 years, table 5 ). Since CS-IgE is also a significant predictor of a positive SPT (table 4), it is likely to have an indirect effect on asthma: CS-IgE $\rightarrow$ SPT positivity $\rightarrow$ asthma. However, sensitisation is not a necessary link in the chain of reactions because, in children who did not develop sensitisation (representing the majority), a strong direct effect between CS-IgE and asthma became obvious (OR 3.35, table 5). We also investigated whether only early sensitisation (at age 4) changed the direct and indirect effect of CS-IgE on asthma and found that the results did not differ substantially from those when SPTs at age 4 and 10 were combined.

Exposure to pets at birth was not associated with CS-IgE levels (table 1) and did not explain the occurrence of allergic 
Table 5 Odds ratios (ORs) and confidence intervals (CI) for the risk of asthma with raised CS-IgE levels (logistic regression analysis)

\begin{tabular}{|c|c|c|c|c|c|c|}
\hline \multirow[b]{2}{*}{ Age } & \multirow[b]{2}{*}{ Strata } & \multirow[b]{2}{*}{$\begin{array}{l}\text { Total sample } \\
\text { (N) }\end{array}$} & \multicolumn{2}{|l|}{ Cord serum IgE levels } & \multirow[b]{2}{*}{$\begin{array}{l}\text { Unadjusted OR } \\
(95 \% \mathrm{Cl})\end{array}$} & \multirow[b]{2}{*}{$\begin{array}{l}\text { Adjustedt OR } \\
(95 \% \mathrm{Cl})\end{array}$} \\
\hline & & & $\begin{array}{l}<0.5 \mathrm{kU} / \mathrm{I} \\
\%(\mathrm{n} / \mathrm{N})\end{array}$ & $\begin{array}{l}\geqslant 0.5 \mathrm{kU} / \mathrm{l} \\
\%(\mathrm{n} / \mathrm{N})\end{array}$ & & \\
\hline $1-2$ & All & 1194 & $10.5 \%(110 / 1044)$ & $8.7 \%(13 / 150)$ & $0.80(0.44$ to 1.47$)$ & 0.72 (0.39 to 1.34$)$ \\
\hline 4 & $\begin{array}{l}\text { All } \\
\text { Positive SPT } \\
\text { Negative SPT } \\
\text { No SPT conducted }\end{array}$ & $\begin{array}{l}1068 \\
175 \\
688 \\
205\end{array}$ & $\begin{array}{l}15.2 \%(141 / 928) \\
30.8 \%(12 / 39) \\
10.7 \%(8 / 75) \\
8.9 \%(16 / 179)\end{array}$ & $\begin{array}{l}15.0 \%(21 / 140) \\
38.5 \%(52 / 136) \\
11.9 \%(73 / 613) \\
3.8 \%(1 / 26)\end{array}$ & $\begin{array}{l}0.98(0.60 \text { to } 1.62) \\
0.71(0.33 \text { to } 1.52) \\
0.88(0.41 \text { to } 1.92) \\
0.41(0.05 \text { to } 3.21)\end{array}$ & $\begin{array}{l}0.92(0.55 \text { to } 1.52) \\
0.60(0.27 \text { to } 1.36) \\
0.90(0.41 \text { to } 1.97) \\
0.54(0.11 \text { to } 2.60)\end{array}$ \\
\hline 10 & $\begin{array}{l}\text { All } \\
\text { Positive SPT } \\
\text { Negative SPT } \\
\text { Incomplete SPT } \\
\text { information } \neq\end{array}$ & $\begin{array}{l}1191 \\
288 \\
485 \\
418\end{array}$ & $\begin{array}{l}11.9 \%(124 / 1040) \\
27.5 \%(14 / 51) \\
16.3 \%(8 / 49) \\
7.6 \%(28 / 367)\end{array}$ & $\begin{array}{l}18.5 \%(28 / 151) \\
30.5 \%(72 / 237) \\
5.5 \%(24 / 436) \\
11.8 \%(6 / 51)\end{array}$ & $\begin{array}{l}1.68(1.07 \text { to } 2.64)^{*} \\
0.86(0.44 \text { to } 1.69) \\
3.81(1.54 \text { to } 9.39)^{*} \\
1.56(0.49 \text { to } 4.93)\end{array}$ & $\begin{array}{l}1.66(1.05 \text { to } 2.62)^{*} \\
0.83(0.41 \text { to } 1.67) \\
3.35(1.41 \text { to } 7.93)^{*} \\
1.77(0.52 \text { to } 6.07)\end{array}$ \\
\hline
\end{tabular}

SPT, skin prick test.

${ }^{*} \mathrm{p}<0.05$.

†Controlling for sex, maternal smoking during pregnancy, age of mother at delivery, maternal and paternal atopy, season of birth, birth weight, neonatal complications, and having a pet at recruitment.

flncludes missing observations at ages 4 and 10 as well as negative SPT at one age and missing at the other.

sensitisation and asthma. The additional control of pet exposure at age 4 and for the number of children in the home, separately and in combination, also had no effect on the results.

It is widely accepted that dramatic changes in immune responses occur during pregnancy and fetal markers of immune response are detected as early as 10-22 weeks gestation. ${ }^{33}$ To prevent the termination of pregnancy the fetomaternal immune system is shifted in a Th2 direction. ${ }^{34}{ }^{35}$ This Th2 shift begins with the secretion of human chorionic gonadotropin which, in turn, stimulates progesterone production. Progesterone then promotes the secretion of Th2 cytokines over the secretion of Thl cytokines. ${ }^{33}$ Although cytokine production may be variable in the early stage of development, the Th1 and Th2 subsets become stable after repeated stimulation. ${ }^{30-32}$ There are two theories as to the time when sensitisation and $\mathrm{T}$ cell stability occurs: the prenatal priming hypothesis which considers that fetal life immunological events are more important in the development of allergy in childhood, and the hygiene hypothesis which considers that the insults happen after birth. Given that CSIgE is a biomarker of prenatal immunological conditions, our findings favour the prenatal priming hypothesis. CS-IgE was associated with overall SPT positivity at ages 4 and 10 (table 4). The presence of a significant adjusted OR for the overall SPT and specific SPTs-both at age 4 and 6 years later-supports this idea. There was a non-significant reduction in the OR of CS-IgE despite the increased percentage of children with a positive SPT at age 10, which may reflect a weakening of the effect of prenatal conditions compared with postnatal events (table 4 , figl).

We observed a stronger association between raised CS-IgE levels and a maternal history of atopy than with a paternal history of atopy (table 1). This is in agreement with previous findings and other evidence that maternal immune responses may influence allergic responses in offspring. ${ }^{36-39}$

CS-IgE had a prognostic value (OR 1.66) for asthma at age 10 years. In the one previous investigation with a comparable follow up time after birth, Croner et al found a fivefold increase in the cumulative incidence of asthma in children at 11 years with CS-IgE levels of $0.9 \mathrm{kU} / \mathrm{l}$ and higher. ${ }^{22}$

At ages $1-2$ and 4 years the minimum criteria for the diagnosis of asthma included three or more separate episodes of wheeze in the previous 12 months, each lasting at least 3 days. At age 10 the definition of asthma was at least one episode of wheezing in the previous 12 months in addition to

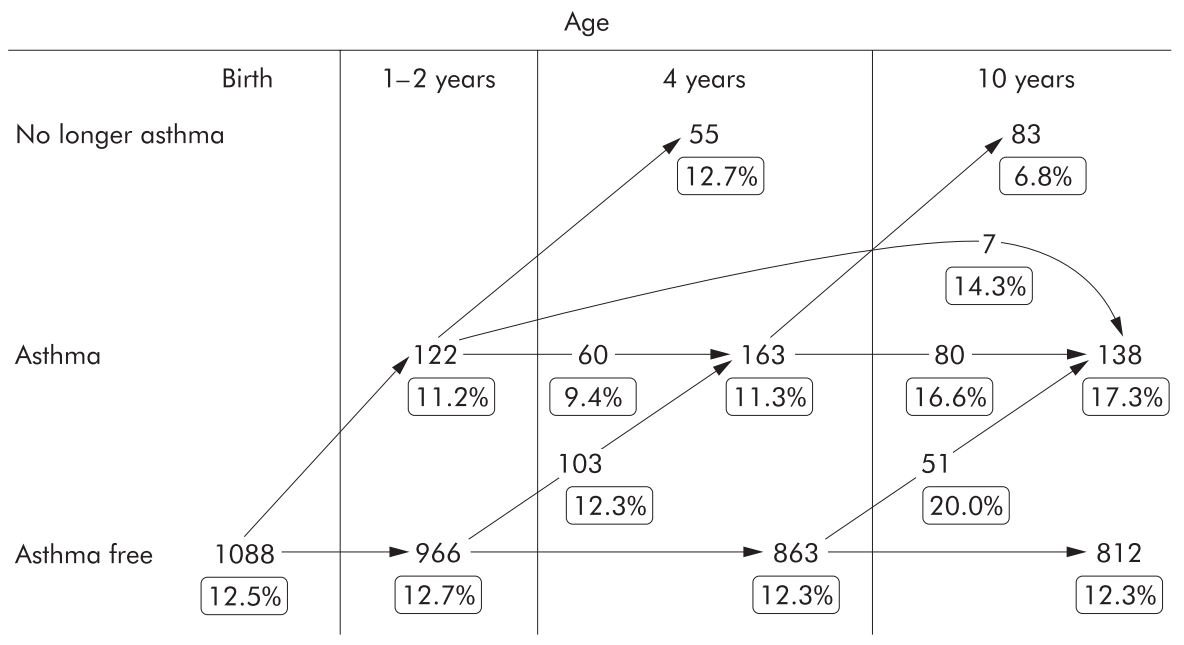

Figure 2 Dynamic for groups of asthmatics diagnosed in different ages and percentages of raised cord serum lgE. 
being diagnosed with asthma by a physician at least once. Different criteria for a diagnosis of asthma at ages 4 and 10 may have led to misclassification. This misclassification, should it exist, would be non-differential. A previous diagnosis of asthma was less likely to have biased an asthma diagnosis at age 10 because fewer children were diagnosed as asthmatics at this age (12.8\%) than at age $4(15.2 \%$, table 5$)$. It is unlikely that the level of CS-IgE affected the asthma diagnosis at age 10 but not at age 4 , as this information was not available to the field workers who collected information on the presence of wheeze and asthma diagnosis.

As already mentioned, there is evidence that early life events may influence atopy and asthma later in life. But how could CS-IgE levels predict asthma at age 10 years and not at an earlier age? One possible explanation is that the diagnosis of asthma in early childhood is based on transient symptoms that tend to disappear later in life. Kurukulaaratchy et a ${ }^{40}$ showed that, in approximately two thirds of children who had wheezing in the first 4 years of life, it had disappeared by the age of 10. In addition, it has been reported that most infants who wheeze are not necessarily atopic and that the wheezing disappears in many as they grow older. ${ }^{41}$ Assuming this kind of "sorting process", the diagnosis of asthma becomes more reliable for children with persistent wheezing. However, our data do not support this explanation as the percentage of those with asthma at ages $1-2,4$ and 10 years (12.5\%) who had raised levels of CS-IgE was not different from those who never had asthma (12.3\%, fig 2$)$.

Another possible explanation is that the late onset of asthma is related to CS-IgE. In this case, we would expect a higher proportion of children with raised CS-IgE levels in the late onset group. In our study, 51 children (fig 2) had asthma at age 10 but not earlier, but only a few of them had wheezing before the age of $10(6 \%$ at age $1-2$ and $10 \%$ at age 4). However, $20 \%$ of these children had raised CS-IgE levels which is the highest proportion of any of the groups studied (fig 2). The next highest proportion of raised CS-IgE levels (16.6\%) was in children who had asthma at age 4 and again at age 10 years. Our results therefore support the late onset theory rather than the "sorting process" explanation.

As shown in fig 1, the trend for ORs for asthma increased until it reached significance at age 10. In addition, the percentage of asthmatics with raised CS-IgE levels was 8.7\% at age $1-2,15.0 \%$ at age 4 , and $18.5 \%$ at age 10 years (table 5 ). This could be seen as a gradual development of asthma in those with raised CS-IgE levels and hence supports the importance of CS-IgE as a biomarker of fetal life events in the development of asthma later in life.

In conclusion, raised cord serum IgE levels measured at birth increase sensitisation to aeroallergens by the ages of 4 and 10 years and the development of asthma at 10 years but not at younger ages. These findings support the importance of prenatal conditioning in the development of allergy later in life. The lack of significance of CS-IgE as a risk factor for asthma early in life may be due to the gradual development of asthma as the cohort aged and the existence of a late onset variety of asthma. Further investigations are needed to increase our understanding of the immunological mechanisms responsible for the effect of fetal life events on childhood allergy. Long term assessments are also needed because of the possibility of late onset childhood allergy.

\section{Authors' affiliations}

A Sadeghnejad, W Karmaus, S Davis, Department of Epidemiology, Michigan State University, East Lansing, Michigan, USA R J Kurukulaaratchy, S Matthews, The David Hide Asthma \& Allergy Research Centre, St Mary's Hospital, Isle of Wight, UK

S H Arshad, Department of Respiratory Medicine, University Hospital of North Staffordshire, Stoke-on-Trent, UK

\section{REFERENCES}

1 Nambu M, Shintaku N, Ohta S. Relationship between cord blood level of IgE specific for Dermatophagoides pteronyssinus and allergic manifestations in infancy. Biol Neonate 2003;83:102-6.

2 Hattevig G, Kjellman B, Bjorksten B. Clinical symptoms and IgE responses to common food proteins and inhalants in the first 7 years of life. Clin Allergy 1987; 17:571-8.

3 Stazi MA, Sampogna F, Montagano G, et al. Early life factors related to clinical manifestations of atopic disease but not to skin-prick test positivity in young children. Pediatr Allergy Immunol 2002;13:105-12.

4 Kjellman NI, Croner S. Cord blood IgE determination for allergy prediction: a follow-up to seven years of age in 1651 children. Ann Allergy 1984;53:167-71.

5 Karmaus W, Arshad H, Mattes J. Does the sibling effect have its origin in utero? Investigating birth order, cord blood immunoglobulin E concentration, and allergic sensitization at age 4 years. Am J Epidemiol 2001;154:909-15.

6 Kaan A, Dimich-Ward H, Manfreda J, et al. Cord blood lgE: its determinants and prediction of development of asthma and other allergic disorders at 12 months. Ann Allergy Asthma Immunol 2000;84:37-42.

7 Orgel HA, Hamburger RN, Bazaral M, et al. Development of lgE and allergy in infancy. J Allergy Clin Immunol 1975;56:296-307.

8 Croner S, Kiellman NI, Eriksson B, et al. IgE screening in 1701 newborn infants and the development of atopic disease during infancy. Arch Dis Child 1982;57:364-8.

9 Ruiz RG, Richards D, Kemeny DM, et al. Neonatal lgE: a poor screen for atopic disease. Clin Exp Allergy 1991;21:467-72.

10 Michel FB, Bousquet J, Greillier P, et al. Comparison of cord blood immunoglobulin E concentrations and maternal allergy for the prediction of atopic diseases in infancy. J Allergy Clin Immunol 1980;65:422-30.

11 Bergmann RL, Edenharter G, Bergmann KE, et al. Predictability of early atopy by cord blood-lgE and parental history. Clin Exp Allergy 1997;27:752-60.

12 Hansen LG, Host A, Halken S, et al. Cord blood IgE. II. Prediction of atopic disease. A follow-up at the age of 18 months. Allergy 1992;47:397-403.

13 Eiriksson TH, Sigurgeirsson B, Ardal B, et al. Cord blood lgE levels are influenced by gestational age but do not predict allergic manifestations in infants. Pediatr Allergy Immunol 1994;5:5-10.

14 Edenharter G, Bergmann RL, Bergmann KE, et al. Cord blood-lgE as risk factor and predictor for atopic diseases. Clin Exp Allergy 1998;28:671-8.

15 Strimas JH, Chi DS. Significance of IgE level in amniotic fluid and cord blood for the prediction of allergy. Ann Allergy 1988;61:133-6.

16 Hide DW, Arshad SH, Twiselton R, et al. Cord serum lgE: an insensitive method for prediction of atopy. Clin Exp Allergy 1991;21:739-43.

17 Tariq SM, Arshad SH, Matthews SM, et al. Elevated cord serum lgE increases the risk of aeroallergen sensitization without increasing respiratory allergic symptoms in early childhood. Clin Exp Allergy 1999;29:1042-8.

18 Arshad SH, Tariq SM, Matthews S, et al. Sensitization to common allergens and its association with allergic disorders at age 4 years: a whole population birth cohort study. Pediatrics 2001;108:E33.

19 Kurukulaaratchy RJ, Fenn M, Twiselton R, et al. The prevalence of asthma and wheezing illnesses amongst 10-year-old schoolchildren. Respir Med 2002;96:163-9.

20 Arshad SH, Stevens M, Hide DW. The effect of genetic and environmental factors on the prevalence of allergic disorders at the age of two years. Clin Exp Allergy 1993;23:504-11.

21 Fletcher R. Clinical epidemiology. In:The essentials.3rd ed. Baltimore: William \& Wilkins, 1996

22 Croner S, Kjellman NI. Development of atopic disease in relation to family history and cord blood lgE levels. Eleven year follow up in 1654 children. Pediatr Allergy Immunol 1990;1:14-20.

23 Magnusson CG. Maternal smoking influences cord serum $\lg E$ and $\lg D$ levels and increases the risk for subsequent infant allergy. J Allergy Clin Immunol 1986;78:898-904.

24 Halonen $M$, Stern D, Taussig $L M$, et al. The predictive relationship between serum IgE levels at birth and subsequent incidences of lower respiratory illnesses and eczema in infants. Am Rev Respir Dis 1992;146:866-70.

25 Haus $M$, Heese HD, Weinberg EG, et al. Genetic and environmental influences on cord blood serum lgE and on atopic sensitisation in infancy. S Afr Med J 1990;77:7-13.

26 Magnusson CG. Cord serum IgE in relation to family history and as predictor of atopic disease in early infancy. Allergy 1988;43:241-51.

27 Arshad $\mathrm{H}$. Influence of genetic and environmental factors on the level of $\lg E$ at birth. Pediatr Allergy Immunol 1992;3:79-83.

28 Kuehr J, Karmaus W, Frischer T, et al. Longitudinal variability of skin prick test results. Clin Exp Allergy 1992;22:839-44.

29 Bodtger U, Jacobsen CR, Poulsen LK, et al. Long-term repeatability of the skin prick test is high when supported by history or allergen-sensitivity tests: a prospective clinical study. Allergy 2003;58:1180-6.

30 Szabo SJ, Jacobson NG, Dighe AS, et al. Developmental commitment to the Th2 lineage by extinction of IL-12 signaling. Immunity 1995;2:665-75.

31 Perez VL, Lederer JA, Lichtman AH, et al. Stability of Th1 and Th2 populations. Int Immunol 1995:7:869-75.

32 Murphy E, Shibuya K, Hosken N, et al. Reversibility of T helper 1 and 2 populations is lost after long-term stimulation. J Exp Med 1996;183:901-13.

33 Jones AC, Miles EA, Warner JO, et al. Fetal peripheral blood mononuclear cell proliferative responses to mitogenic and allergenic stimuli during gestation. Pediatr Allergy Immunol 1996;7:109-16.

34 Gaunt G, Ramin K. Immunological tolerance of the human fetus. Am J Perinatol $2001 ; 18: 299-312$. 
35 Margni RA, Zenclussen AC. During pregnancy, in the context of a Th2-type cytokine profile, serum IL-6 levels might condition the quality of the synthesized antibodies. Am J Reprod Immunol 2001;46:181-7.

36 Kuehr J, Karmaus W, Forster J, et al. Sensitization to four common inhalant allergens within 302 nuclear families. Clin Exp Allergy 1993;23:600-5.

37 Johnson CC, Ownby DR, Peterson EL. Parental history of atopic disease and concentration of cord blood IgE. Clin Exp Allergy 1996;26:624-9.

38 Wright AL, Taussig LM. Lessons from long-term cohort studies. Childhood asthma. Eur Respir J Suppl 1998;27:17s-22s.
39 Illi S, von Mutius E, Lau S, et al. The pattern of atopic sensitization is associated with the development of asthma in childhood. J Allergy Clin Immunol 2001;108:709-14.

40 Kurukulaaratchy RJ, Fenn MH, Waterhouse LM, et al. Characterization of wheezing phenotypes in the first 10 years of life. Clin Exp Allergy 2003;33:573-8.

41 Taussig LM, Wright AL, Holberg CJ, et al. Tucson Children's Respiratory Study: 1980 to present. J Allergy Clin Immunol 2003;111:661-75, quiz 676.

\section{LUNG ALERT}

\section{Is Propionibacterium acnes the cause of sarcoidosis?}

$\Delta$ Nishiwaki T, Yoneyama H, Eishi Y, et al. Indigenous pulmonary Propionibacterium acnes primes the host in the development of sarcoid-like pulmonary granulomatosis in mice. Am J Pathol 2004;165:631-9

arcoidosis is a chronic granulomatous disorder of unknown aetiology. This study

reports the induction in mice of pulmonary granulomas, similar to those in sarcoidosis,

by indigenous Propionibacterium acnes residing in the lower respiratory tract. This was associated with an influx of $P$ acnes sensitised CD4+ T lymphocytes from the circulation and, moreover, eradication of $P$ acnes with antibiotics led to resolution of the granulomas.

Immunostaining and reverse-transcriptase polymerase chain reaction were used to demonstrate $P$ acnes antigen in the lungs and lymph nodes of the mice. Furthermore, lymphocytes from these animals proliferated specifically to $P$ acnes antigen, suggesting prior priming. In a subsequent experiment mice were immunised with $P$ acnes antigen and $P$ acnes sensitised CD4+ T cells were isolated from the inguinal nodes. These $\mathrm{T}$ cells were then injected into normal mice and the lungs and liver showed granulomatous changes when examined histologically 2 weeks later. Repeated immunisation with $P$ acnes produced granulomas in the liver, lung and spleen with CD4+ cells expressing interferon- $\gamma$ but not interleukin-4 (suggesting a Thl type response), along with increases in the serum calcium and angiotensin-converting enzyme concentrations. Finally, bronchoalveolar lavage performed after immunisation showed increased numbers of both total and CD4+ cells, and the above responses were alleviated by prior intratracheal administration of antibiotics.

This study proposes that the immune response against indigenous $P$ acnes may play a role in the pathogenesis of sarcoidosis, and that antibiotics directed against $P$ acnes may be a potentially effective treatment in this disease.

S Mukheriee

Specialist Registrar, Queen's Hospital, Burton-upon-Trent, UK; smukherjee66@yahoo.com 